\title{
Effects of branched-chain amino acids on glucose uptake and lactose synthesis rates in bovine mammary epithelial cells and lactating mammary tissue slices
}

\author{
J. V. V. Silva, ${ }^{1} \odot$ S. Ganesan, ${ }^{1}$ H. K. J. P. Wickramasinghe, ${ }^{1} \odot$ N. Stepanchenko, ${ }^{1}$ C. A. Kaya, ${ }^{2} \odot$ D. C. Beitz, ${ }^{1} \odot$ \\ and J. A. D. R. N. Appuhamy ${ }^{1 *}$ (1) \\ ${ }^{1}$ Department of Animal Science, lowa State University, Ames 50011 \\ ${ }^{2}$ Department of Livestock and Crop Production, Dicle University, Diyarbakir, 21280, Turkey
}

\begin{abstract}
Even though supplementations of essential AA (EAA) are often related to increased lactose yields in dairy cows, underlying mechanisms connecting EAA availability to the mammary glands and lactose synthesis are poorly understood. The objective of this study was to examine the effects of branched-chain AA (BCAA) including Leu, Ile, and Val on (1) glucose transporter (GLUT1) abundance and glucose uptake, (2) the abundance of proteins regulating lactose synthesis pathway, and (3) fractional synthesis rates of lactose (FSR) using bovine mammary epithelial cells (BMEC) and mammary tissues slices (MTS). The BMEC $(\mathrm{n}=4)$ were allocated randomly to regular Dulbecco's Modified Eagle Medium with Ham's F12 (DMEM/F12) medium $(+\mathrm{EAA})$ or +EAA deficient (by 90\%) in all EAA (EAA), all BCAA (-BCAA), only Leu (-Leu), only Ile (-Ile) or only Val (-Val). Western immunoblotting analyses, depletion of glucose in media, and a proteomic analysis were performed to determine the abundance of GLUT1 in the cell membrane, net glucose uptake, and the abundance of enzymes involved in lactose synthesis pathway in BMEC, respectively. The MTS $(\mathrm{n}=6)$ were allocated randomly to DMEM/F12 medium having all EAA and ${ }^{13} \mathrm{C}$-glucose at concentrations similar to plasma concentrations of cows $\left(+\mathrm{EAA}_{\mathrm{p}}\right)$, and $+\mathrm{EAA}_{\mathrm{p}}$ deprived of all BCAA $\left(-\right.$ BCAA $\left._{p}\right)$ or only Leu $\left(-\mathrm{Leu}_{\mathrm{p}}\right)$ for $3 \mathrm{~h}$. The ${ }^{13} \mathrm{C}$ enrichments of free glucose pool in $\operatorname{MTS}\left(E_{\text {Glu-free }}\right)$ and the enrichments of glucose incorporated into lactose in MTS and media [ $E_{\text {Lactose-bound (TEYM) }}$ ] were determined and used in calculating FSR. In BMEC, - BCAA increased the fraction of total GLUT1 translocated to the cell membrane and the fraction that was potentially glycosylated compared with +EAA. Among individual BCAA, only - Leu was associated
\end{abstract}

Received July 1, 2021.

Accepted October 15, 2021.

*Corresponding author: appuhamy@iastate.edu with a $63 \%$ increase in GLUT1 translocated to the cell membrane and a $40 \%$ increase in glucose uptake of BMEC. The -BCAA tended to be related to a $75 \%$ increase in the abundance of hexokinase in BMEC. Deprivation of Leu tended to increase glucose uptake of MTS but did not affect $E_{\text {Glu-free, }}, E_{\text {Lactose-bound (TEM), }}$, or FSR relative to $+\mathrm{EAA}_{\mathrm{p}}$. On the other hand, $-\mathrm{BCAAp}$ did not affect glucose uptake of MTS but was related to lower $E_{\text {Lactose-bound (TBM) }}$, or FSR relative to $+\mathrm{EAA}_{\mathrm{p}}$. Considering together, decreasing Leu supply to mammary tissues enhances GLUT1 and thus glucose uptake, which, however, does not affect lactose synthesis rates. Moreover, the deficiency of other BCAA, Ile, and Val alone or together with the deficiency of Leu seemed to decrease lactose synthesis rates without affecting glucose uptake. The data also emphasize the importance of addressing the effect of the supply of other nutrients to the mammary glands than the precursor supply in describing the synthesis of a milk component.

Key words: isoleucine, leucine, hexokinase, N-glycosylation

\section{INTRODUCTION}

Branched-chain AA (BCAA) including Leu, Ile, and Val, represent about $40 \%$ of the total EAA supply to the mammary glands of dairy cows (Curtis et al., 2018). Leucine and Ile serve as stimuli for cellular signals controlling milk protein synthesis in mammary epithelial cells and tissues (Appuhamy et al., 2012; Arriola Apelo et al., 2014). The mammary glands extract BCAA from blood in excess compared with the amount required for milk protein synthesis (Clark, 1975; Lapierre et al., 2012). The surplus BCAA serve as energy substrates and provide carbon and nitrogen for the synthesis of NEAA (Wohlt et al., 1977). Through a meta-analysis, Lapierre et al. (2010) highlighted a positive relationship between postruminal infusions of casein or AA and lactose yields in dairy cows. The AA can increase lactose yield by contributing to hepatic and renal glu- 
coneogenesis, and thus to the whole body $(\mathbf{W b})$ rate of appearance (Ra) of glucose (Hunter and Millson, 1964; Huntington et al., 2006). However, as Lapierre et al. (2010) have also pointed out, Clark et al. (1977) and Lemosquet et al. (2009a) support the idea that the AA supply can improve lactose yields independent of their contribution to glucose Wb Ra. Consistently, Lemosquet et al. (2009b) reported albeit glucose Wb Ra increased, lactose yield remained unchanged for glucose or propionate infusions in lactating dairy cows. They observed the same responses for infusion of NEAA postulating that some EAA would be involved in regulating lactose synthesis in the mammary glands independent of the glucose supply.

Lactose is composed of a molecule of galactose bound to a molecule of glucose by a $\beta-1,4$-glycosidic linkage. It is the main carbohydrate in milk and is a major energy source for young mammals. Glucose uptake into the mammary cells, conversion of glucose to uridine diphosphate (UDP)-galactose, transportation of UDP-galactose to Golgi vesicles, and galactosylation of glucose with UDP-galactose to produce lactose in Golgi vesicles are significant events of lactose biosynthesis pathway taking place exclusively in the mammary glands (Kuhn et al., 1980). The glucose transporter member 1 (GLUT1) is the most abundant glucose transporter in the mammary glands of lactating cows (Zhao and Keating, 2007). The gene expression of GLUT1 increases nearly 6-fold once lactation is initiated and thus, is hypothesized to be rate-limiting for lactose synthesis (Komatsu et al., 2005; Zhao and Keating, 2007; Zhang et al., 2018). Hormones, such as prolactin, and glucose regulate the abundance and activity of GLUT1 and some critical enzymes in the lactose synthesis pathway (Ip and Dao, 1978; Riskin et al., 2008; Lin et al., 2016). It is hard to find evidence supporting such regulatory roles for $\mathrm{AA}$ in the literature. Considering the potential to stimulate anabolic signals in mammary cells, an involvement of BCAA in regulating lactose synthesis can be speculated. Leucine or Ile supplementations upregulate the cell membrane abundance of GLUT1 and glucose uptake in muscle and the small intestine of pigs and rats (Nishitani et al., 2005; Zhang et al., 2016). Jugular infusion of all 3 BCAA, however, did not alter net mammary uptake of glucose or lactose yield in dairy cows (Curtis et al., 2018). On the other hand, individual BCAA seem to have opposite effects on lactose synthesis in dairy cows as a duodenal infusion of Leu decreased lactose yields (Rulquin and Pisulewski, 2006), whereas abomasal or jugular infusions of Ile tended to increase lactose yields (Robinson et al., 1999; Yoder et al., 2020). Overall, the associations between EAA and the synthesis of lactose in cow mammary glands are yet to be fully comprehended. On the basis of previous research, we hypothesize that BCAA, individually or in combination, influence the ability of the bovine mammary glands to synthesize lactose. To test this hypothesis, the objective of this study was to investigate the effects of total or individual BCAA on (1) GLUT1 abundance and glucose uptake, (2) the abundance of key enzymes regulating lactose synthesis, and (3) lactose synthesis rates using bovine mammary epithelial cells (BMEC) and mammary tissue slices (MTS) from lactating Holstein cows.

\section{MATERIALS AND METHODS}

All animal procedures in this study were conducted under approval of the Animal Care and Use Committee at Iowa State University. Bovine mammary epithelial cells used in this study were from Mark Hanigan's laboratory at Virginia Polytechnic Institute and State University (Blacksburg, VA). The development of this cell line is comprehensively described in $\mathrm{Hu}$ et al. (2009). We used 23 to 27 passages of BMEC in the present study. Cells in each replicate of each experiment described below came from one of those passages. The epithelial nature and abilities of BMEC to produce milk components were described previously in RuizCortes et al. (2017) and Ganesan et al. (2019). Lin et al. (2016) demonstrated statistically significant $(P$ $<0.05)$ responses of the abundance of GLUT1 and other proteins involved in lactose synthesis pathway, and lactose synthesis rates in BMEC by using 3 independent replicates. Therefore, we included more than 3 replicates $(\mathrm{n}=4$ to 6$)$ in our experiments expecting a reasonable statistical power.

\section{Effects of BCAA on the Abundance of GLUT1 and Net Glucose Uptake of BMEC}

Experiment 1. On 4 different days, BMEC from each of 23 to 26 cell passages $(n=4)$ were seeded in 3 T75 flasks $\left(2 \times 10^{6}\right.$ cells per flask $)$ and incubated in DMEM/F12 medium (Cat\# 12400024; Thermo Fisher Scientific) containing $10 \%$ fetal bovine serum (FBS, Cat\# 10437028; Thermo Fisher Scientific), $0.1 \mathrm{mg} / \mathrm{L}$ bovine insulin (Cat\# 11070-73-8; Sigma Aldrich), 1\% of a $100 \times$ antibiotic-antimycotic mix (Cat\# 15240062; Thermo Fisher Scientific), and $14.0 \mathrm{~m} M$ sodium bicarbonate at $37^{\circ} \mathrm{C}$ under $5 \% \mathrm{CO}_{2}$ until cells reached $90 \%$ confluency. After the serum-containing media was discarded, the cells were washed twice with $10 \mathrm{~mL}$ of PBS (Cat\# 70011044; Thermo Fisher Scientific) and then treated with 3 serum-free media, (1) regular DMEM/ F12 medium with all EAA (+EAA), (2) +EAA deficient (by 90\%) in only the 3 BCAA (-BCAA), and (3) +EAA deficient (by 90\%) in all EAA (-EAA). The 
-BCAA and -EAA were made by adding individual EAA (Sigma Aldrich) to a custom-made DMEM/F12 medium devoid of all EAA (Thermo Fisher Scientific). The concentrations of individual EAA in each treatment medium are given in Table 1 . All 3 treatment media ( $\mathrm{pH}=7.4$ ) contained $3.7 \mathrm{~m} M$ total NEAA, $17.5 \mathrm{~m} M$ glucose, $0.1 \mathrm{mg} / \mathrm{L}$ bovine insulin, $1 \%$ of the antibiotic-antimycotic mix, and $14.0 \mathrm{mM}$ sodium bicarbonate. The BMEC were incubated in treatment media at $37^{\circ} \mathrm{C}$ and $5 \% \mathrm{CO}_{2} / 95 \% \mathrm{O}_{2}$ for $24 \mathrm{~h}$. The 24 -h incubation was chosen to obtain a satisfactory level of cellular protein expression as demonstrated previously by Lin et al. (2016) for GLUT1 and some other proteins in the lactose synthesis pathway and $\mathrm{Lu}$ et al. (2012) for proteins in the milk protein synthesis pathway of cow mammary epithelial cells. Because the treatments of this study were related to AA availability to the cells, we also expected the cellular protein abundance to respond quickly to the treatments.

Upon completion of the incubation, cells were dissociated from flasks by incubating in $5 \mathrm{~mL}$ of $0.05 \%$ trypsin for $10 \mathrm{~min}$. The resulting cell suspension was centrifuged at $1,000 \times g$ at $20^{\circ} \mathrm{C}$ for $7 \mathrm{~min}$ to separate cells into a pellet. Approximately one-third of the pellet was saved for a proteomic analysis described below. The remaining cell pellet was processed to harvest cytosolic and membrane protein fractions by using a commercial kit including a washing buffer, a permeabilization buffer, and a solubilization buffer (Cat\#: 89842, Thermo Fisher Scientific) by following the manufacturer's protocol with some modifications. Briefly, the cells were washed twice with the washing buffer and then incubated in $500 \mu \mathrm{L}$ of the permeabilization buffer at $4.0^{\circ} \mathrm{C}$ for $10 \mathrm{~min}$. Following incubation, the cell suspen- sion was centrifuged at $4^{\circ} \mathrm{C}$ and $16,000 \times g$ for $15 \mathrm{~min}$. and the supernatant containing the cytosolic proteins was separated and saved immediately at $-80^{\circ} \mathrm{C}$. Then, $300 \mu \mathrm{L}$ of the solubilization buffer was added to the remaining cell pellet, incubated at $4.0^{\circ} \mathrm{C}$ for $30 \mathrm{~min}$, and centrifuged at $4^{\circ} \mathrm{C}$ and $16,000 \times g$ for $15 \mathrm{~min}$. The supernatant containing membrane proteins was then separated and saved immediately at $-80^{\circ} \mathrm{C}$. Both permeabilization and solubilization buffers contained $1 \%$ of a protease and phosphatase inhibitor cocktail (Cat\# 78440, Thermo Fisher Scientific).

Experiment 2. Experiment $1(\mathrm{n}=4)$ was repeated by incubating BMEC in 4 treatment media: (1) +EAA, (2) +EAA deficient in only Leu (-Leu), (3) +EAA deficient in only Ile (-Ile), and (4) +EAA deficient in only Val (-Val). Except individual BCAA concentrations (Table 1), concentrations of other constituents of media were the same as those in experiment 1 . Upon completion of incubation, the cytosolic and membrane protein fractions were isolated as described in experiment 1.

Experiment 3. The BMEC from 5 passages (23 to $27)$ were seeded separately in five 6 -well plates $(0.25$ $\times 10^{6} /$ well) and incubated in regular DMEM/F12 medium containing 10\% FBS until $90 \%$ confluency. After discarding serum-containing medium and washing twice with PBS, cells were glucose-starved by incubating for $1 \mathrm{~h}$ in +EAA that was deprived of glucose. Following the starvation, cells were washed twice with PBS. Then, cells in 2 wells of each plate were incubated in $500 \mu \mathrm{L} /$ well of (1) +EAA, (2) -Leu, or (3) -Ile for $3 \mathrm{~h}$. Before beginning the incubation, a sample of each medium was saved for analysis of glucose concentration. The 3-h incubation was chosen as it was similar to

Table 1. Amino acid and glucose concentrations in treatment media used in the present study

\begin{tabular}{|c|c|c|c|c|c|c|c|c|c|}
\hline Nutrient & \multicolumn{6}{|c|}{ Treatment for $\mathrm{BMEC}^{1}$} & \multicolumn{3}{|c|}{ Treatment for MTS ${ }^{2}$} \\
\hline \multicolumn{10}{|l|}{ EAA, $m M$} \\
\hline Ile & 0.42 & 0.042 & 0.042 & 0.42 & 0.042 & 0.42 & 0.11 & 0.11 & 0 \\
\hline Val & 0.45 & 0.045 & 0.045 & 0.45 & 0.45 & 0.045 & 0.23 & 0.23 & 0 \\
\hline Arg & 0.70 & 0.70 & 0.070 & 0.70 & 0.70 & 0.70 & 0.09 & 0.09 & 0.09 \\
\hline Met & 0.12 & 0.12 & 0.012 & 0.12 & 0.12 & 0.12 & 0.02 & 0.02 & 0.02 \\
\hline Phe & 0.22 & 0.22 & 0.022 & 0.22 & 0.22 & 0.22 & 0.04 & 0.04 & 0.04 \\
\hline Thr & 0.45 & 0.45 & 0.045 & 0.45 & 0.45 & 0.45 & 0.09 & 0.09 & 0.09 \\
\hline $\operatorname{Trp}$ & 0.04 & 0.04 & 0.004 & 0.04 & 0.04 & 0.04 & 0.01 & 0.01 & 0.01 \\
\hline Glucose, $\mathrm{m} M$ & 17.5 & 17.5 & 17.5 & 17.5 & 17.5 & 17.5 & 3.15 & 3.15 & 3.15 \\
\hline
\end{tabular}

${ }^{1}$ BMEC = bovine mammary epithelial cells; +EAA = regular Dulbecco's Modified Eagle Medium with Ham's F12 (DMEM/F12) including all $\mathrm{EAA} ;-\mathrm{BCAA}=+\mathrm{EAA}$ deficient (by $90 \%$ ) in only the $3 \mathrm{BCAA} ;-\mathrm{EAA}=+$ EAA deficient (by $90 \%$ ) in all EAA; - Leu $=+$ EAA deficient (by $90 \%$ ) in only Leu; - Ile = +EAA deficient (by 90\%) in only Ile; - Val = +EAA deficient (by 90\%) in only Val.

${ }^{2} \mathrm{MTS}=$ mammary tissue slices; $+\mathrm{EAA}_{\mathrm{p}}=\mathrm{DMEM} / \mathrm{F} 12$ medium containing EAA and glucose at concentrations similar to plasma concentrations of cows; $-\mathrm{Leu}_{\mathrm{p}}=+\mathrm{EAA}_{\mathrm{p}}$ deprived of only Leu; $-\mathrm{BCAA}_{\mathrm{p}}=+\mathrm{EAAp}$ deprived of Leu, Ile, and Val. 
the duration of incubation in forthcoming experiments using MTS. Upon completion of the incubation, $50 \mu \mathrm{L}$ of medium from each well was sampled. The medium samples were pooled by 2 wells receiving the same treatment and saved for analysis of glucose concentration $(\mathrm{n}=5)$. Cells in each well were harvested into 250 $\mu \mathrm{L}$ of lysis buffer containing $50 \mathrm{~m} M$ Tris HCL and 1.0 $\mathrm{m} M$ EDTA at $\mathrm{pH}$ of 8.5 by mechanical scraping. Total protein concentration in pooled samples of cell lysates was analyzed by using a commercial kit (BCA Assay kit, Thermo Scientific). Glucose concentrations in the media at the beginning and the end of 3 -h incubation were measured also using a commercial kit (Wako Diagnostics) following the manufacturer's protocol.

Experiment 4. Experiment 3 was repeated by incubating BMEC for $24 \mathrm{~h}$ in serum-free DMEM/ F12 medium having 3 concentrations of Leu: (1) 0.2 $\mathrm{m} M$ (close to physiological concentration in plasma of cows), (2) $0.4 \mathrm{mM}$ (the concentration in +EAA), and (3) $2.0 \mathrm{mM}$. The concentration of glucose was maintained at regular DMEM/F12 medium concentration $(17.5 \mathrm{mM})$, which is about 5 times greater than the plasma glucose concentration of dairy cows. While cells were being incubated, medium samples of each 2 -well column $(50 \mu \mathrm{L} /$ well $)$ receiving the same treatment were collected and pooled at $1,6,12$, and $24 \mathrm{~h}$ and analyzed for glucose concentration by using the commercial kit used in experiment 3 .

\section{Effects of BCAA on Lactose Synthesis in Mammary Tissue Slices}

Three Holstein cows producing 14 to $18 \mathrm{~kg} / \mathrm{d}$ of milk in late stage of lactation were fasted for $16 \mathrm{~h}$ and then slaughtered on 3 separate days to obtain mammary parenchymal tissue. A veterinarian at Iowa State University slaughtered cows and harvested 2 chunks of tissue each weighing approximately $500 \mathrm{~g}$ from 2 separate quarters. Mammary tissue slices weighing on average $119 \pm 21 \mathrm{mg}$ were then prepared by using a hand-held microtome as described in Appuhamy et al. (2012). Before being assigned to treatments, each MTS was rinsed with ice-cold PBS to remove any milk residue and then gently blotted dry with tissue paper. Tissue slice preparation and treatment assignments were completed within $1.5 \mathrm{~h}$ after cows had been slaughtered. Two MTS representing separate quarters of each cow were assigned to 1 of 3 treatments in experiment 5 described below. Because MTS were assigned randomly and independently to each treatment medium, one tissue slice was considered as one experimental unit (Lazic et al., 2018).

Experiment 5. Two MTS representing separate quarters of each of the 3 cows were assigned to 1 of 3 treatment media $(\mathrm{n}=6)$ : (1) serum-free DMEM/F12 medium containing all essential amino acids at physiological concentrations $\left(+\mathbf{E A A} \mathbf{A}_{\mathbf{p}}\right) ;(2)+\mathrm{EAA}_{\mathrm{p}}$ deprived of only Leu $\left(-\mathbf{L e u}_{\mathrm{p}}\right)$; and $(3)+\mathrm{EAA}_{\mathrm{p}}$ deprived of all 3 BCAA $\left(-\mathbf{B C A A}_{\mathrm{p}}\right)$. All media contained ${ }^{13} \mathrm{C}$-labeled glucose $\left(\left[1,2-{ }^{13} \mathrm{C}\right]\right.$-glucose, $99 \%$ purity, Cambridge Isotope Laboratories Inc.) at physiological concentration as the sole source of extracellular glucose. The EAA and glucose concentrations in media are given in Table 1. Those concentrations were determined based on the plasma concentrations of lactating dairy cows reported in Curtis et al. (2018). Each MTS was incubated in 4 $\mathrm{mL}$ of treatment medium in 25-mL Erlenmeyer flasks sealed with rubber stoppers in a shaking incubator at $37^{\circ} \mathrm{C}$ for $3 \mathrm{~h}$. Each flask was purged with a 95:5 mix of $\mathrm{O}_{2}: \mathrm{CO}_{2}$ for $20 \mathrm{~s}$ at the beginning and once in every hour during the incubation. Bartley et al. (1966) incubated rat MTS for $3 \mathrm{~h}$ in a similar manner and determined successfully ${ }^{14} \mathrm{C}$-glucose incorporated into lactose. Once the incubation was completed, MTS were rinsed in icecold PBS to remove any residue of media, blotted dry with tissue paper, flash-frozen in liquid nitrogen, and immediately stored at $-80^{\circ} \mathrm{C}$.

\section{Immunocytochemistry Analysis of GLUT1 in BMEC}

The ability of a polyclonal antibody with bovine reactivity (Cat\#: NB110-39113; Novus Biologicals) to identify GLUT1 in BMEC was tested by using an immunocytochemistry analysis. The BMEC were seeded $\left(1 \times 10^{5}\right.$ cells/well) in a 4 -well glass slide (Cat\#: PEZGS0416, Sigma Aldrich) and incubated at $37^{\circ} \mathrm{C}$ for $24 \mathrm{~h}$ until cells achieved $90 \%$ confluency. Then the cells were washed with PBS thrice, and fixed with $10 \%$ formaldehyde for 10 min at room temperature. Following fixing, cells were washed twice with PBS and then incubated in 0.5\% Triton X-100 (Cat\#: 9002-93-1, Sigma Aldrich) in PBS (PBST) at room temperature for 10 min. After washing thrice with PBS, the slides were blocked with 10\% goat serum (Cat\#: 16210064, Thermo Fisher Scientific) in PBS for $1 \mathrm{~h}$. After washing twice with PBST, the slides were incubated with the GLUT1 antibody in the blocking buffer $(1: 200)$ at $4^{\circ} \mathrm{C}$ overnight. The slides were washed thrice with PBST and incubated in a goat antirabbit $\operatorname{IgG}\left(\mathrm{H}^{+} \mathrm{L}\right)$ secondary antibody (Cat\#: 65-6111, Thermo Fisher Scientific) at room temperature for $1 \mathrm{~h}$. Following 3 washes with PBST, slides were dried for 3 min, counter-stained with 4, 6-diamidino-2-phenylindole (Cat\#: P36935, Thermo Fisher Scientific), and sealed with coverslips (Cat\#: 3318, Thermo Fisher Scientific). The images were taken by using a fluorescent microscope (Leica Microsystems). The image given in Figure 1 indicates that the antibody was able to identify GLUT1 local- 


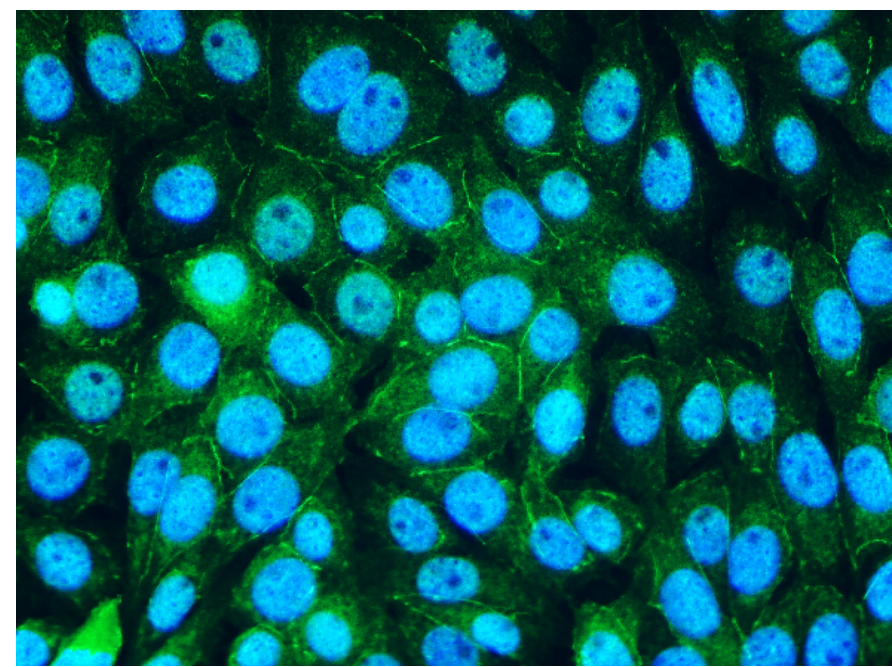

Figure 1. Immunofluorescence detection of the localization of GLUT1 in bovine mammary epithelial cells, which were fixed and permeabilized at room temperature. After the cells had been stained first with GLUT1 antibody (cat\#: NB110-39113; Novus Biologicals) and then with $\operatorname{IgG}\left(\mathrm{H}^{+} \mathrm{L}\right)$ secondary antibody, cells were counter-stained with 4-6-diamidino-2-phenylindole. The immunofluorescence was visualized using a fluorescent microscope (Leica Microsystems).

ized in both the cell membrane and the cytoplasm of BMEC.

\section{Western Immunoblotting Analysis of GLUT1}

Once total protein concentration in cytosolic or membrane fractions of BMEC was determined, each fraction was prepared for western immunoblotting (WB) analysis, where 20 to $30 \mu \mathrm{g}$ of protein was electrophoretically separated and transferred to a polyvinylidene difluoride membrane. Both membrane and cytosolic proteins of all treatments of a given passage (replicate) in a given experiment were run in the same gel (Cat\#: 4561086, Bio-Rad Life Sciences). In experiment $1(\mathrm{n}=4)$, the proteins of all treatments (+EAA, -BCAA, and -EAA) belonging to 2 passages were run in one 15-well gel, while the proteins of the other 2 passages were run in a separate 15 -well gel. In experiment $2(\mathrm{n}=4)$, the proteins of all treatments $(+\mathrm{EAA},-\mathrm{Leu},-\mathrm{Ile}$, and $-\mathrm{Val})$ of a given passage were run in 1 of 4 separate 10-well gels. Once proteins were transferred to the membranes, the remaining binding sites on the blots were blocked with $5 \%$ nonfat milk. Each blot was incubated overnight with the GLUT1 antibody in the blocking buffer (1:1,000, vol:vol). Blots were subsequently washed 3 times (5 min each) with PBS containing 1\% Tween-20 (Bio-Rad Life Sciences), incubated for $1 \mathrm{~h}$ with a horseradish peroxidase-linked secondary antibody (Cell Signaling) in the blocking buffer (1:4,000, vol:vol), washed 3 times with the PBS, treated with chemiluminescent substrates (LI-COR Biosciences), and scanned by using a C-DiGit Blot Scanner (LI-COR Biosciences). Band intensities were quantified by using the Image Studio software (version 5.0, LI-COR Biosciences). The band intensities of each replicate were normalized to corresponding positive control (+EAA) of each replicate before being used in the statistical analysis.

\section{A Proteomic Analysis of the Abundance of Proteins Regulating Lactose Synthesis}

Proteins were harvested from the portion of the cell pellet saved in experiment 1 by using a lysis buffer containing $50 \mathrm{~m} M$ Tris $\mathrm{HCl}$ and $1.0 \mathrm{~m} M$ EDTA at $\mathrm{pH}$ of 8.5. The harvested proteins were subjected to an LC-MS-based proteomics analysis to determine the abundance of key enzymes involved in the lactose biosynthesis pathway. This proteomic analysis was performed in the protein facility at Iowa State University (Ames, IA). Peptide Retention Time Calibration mixture (PRTC, Thermo Scientific) serving as an internal control and $10 \mu \mathrm{g}$ of peptides representing membrane or cytosolic proteins $(250 \mathrm{fmol})$ were injected onto a liquid chromatography column (Agilent Zorbax SB-C18, $0.5 \mathrm{~mm} \times 150 \mathrm{~mm}, 5 \mu \mathrm{m}$ ) and separated by using an Agilent 1260 Infinity Capillary Pump. The separated peptides were analyzed by using a Q Exactive Hybrid Quadrupole-Obitrap Mass Spectrometer (Thermo Fisher Scientific) with an HCD fragmentation cell. The resulting intact and fragmentation patterns were compared with a theoretical fragmentation pattern to identify peptides (MASCOT for the sample peptides, and Sequest HT for the PRTC peptides). The relative abundance of the identified proteins was based on the areas of the top 3 unique peptides for each sample. The protein abundances were normalized to the abundance of actin before being used in the statistical analysis of treatment effects.

\section{Analysis of ${ }^{13} \mathrm{C}$ Enrichments of Sugar Pools in MTS and Media}

Both medium and tissue homogenate samples in experiment 5 were subjected to a GC-MS analysis in W. M. Keck Metabolomics Research Laboratory at Iowa State University (Ames, IA) to quantify the ${ }^{13} \mathrm{C}$ Enrichments. Samples were prepared according to the method published previously by Chen et al. (2015) and Wu et al. (2010). We used 90\% methanol (vol:vol) to extract polar sugars including glucose, galactose, and lactose in MTS or medium. About $100 \mathrm{mg}$ of tissue or $500 \mu \mathrm{L}$ of medium was transferred into centrifuge tubes containing $700 \mu \mathrm{L}$ of $90 \%$ methanol. To each sample was added 
$10 \mu \mathrm{L}$ of ribitol $(1.5 \mathrm{mg} / \mathrm{mL}$ of water $)$ serving as the internal standard and it was homogenized in a bead mill for $3 \mathrm{~min}$. The homogenates were sonicated at $26^{\circ} \mathrm{C}$ for $5 \mathrm{~min}$ and subsequently centrifuged at $16.3 \times \mathrm{g}$ for $8 \mathrm{~min}$. The supernatant was transferred to gas chromatography vials and dried overnight. The dried extracts were subjected to methoximation with methoxyamine hydrochloride $(50 \mu \mathrm{L}$ of $20 \mathrm{mg} / \mathrm{mL}$ in pyridine) and incubated at $30^{\circ} \mathrm{C}$ for $90 \mathrm{~min}$. Samples were then added with $70 \mu \mathrm{L}$ of bis-(trimethylsilyl)-trifluoroacetamide containing $1 \%$ trimethylchlorosilane, and incubated at $42^{\circ} \mathrm{C}$ for $30 \mathrm{~min}$. One microliter from each sample was injected ( split ratio $=1: 40$ ) and subjected to a GC-MS analysis (a 7890C GC coupled with a 5975C MSD). The peaks corresponding to labeled and unlabeled sugars were identified and quantified by using Automated Mass Spectral Deconvolution and Identification System with a manually curated retention-indexed GC-MS library. Additional identifications were performed by using the NIST17-Wiley11 GC-MS spectral library. Data matrices were exported to Excel using Agilent MassHunter Quantitative Analysis 10.0 software (Kim et al., 2016). Retention times of the spectra were determined by using labeled glucose and lactose before actual samples had been tested.

\section{Calculations}

The degree of translocation of GLUT1 from cytosol to cell membrane $\left(D_{\text {Trans }}\right)$ was calculated by using the following equation adopted from the equation in Duhlmeier et al. (2005).

$$
D_{\text {Trans }}=\frac{G L U T 1_{M}}{\left(G L U T 1_{M}+G L U T 1_{C}\right)},
$$

where $G L U T 1_{M}=$ the abundance of GLUT1 in the membrane fraction of proteins, $G L U T 1_{C}=$ the abundance of GLUT1 in the cytosolic fraction of proteins, and $\left(G L U T 1_{M}+G L U T 1_{C}\right)=$ the total abundance of GLUT1. The band densities from WB analyses were used as the abundances.

There were 2 distinct bands, one at $55 \mathrm{kDa}$ and the other between 34 and $43 \mathrm{kDa}$ in western blots probed with the GLUT1 antibody (Figure 2). Asano et al. (1991, 1993) demonstrated 2 forms of GLUT1 one at $38 \mathrm{kDa}$ and the other at $50 \mathrm{kDa}$ in western blots representing nonglycosylated and glycosylated forms of GLUT1, respectively. Therefore, the degree of potential glycosylation of GLUT1 $\left(D_{\text {Glyco }}\right)$ in BMEC were calculated as follows.

$$
D_{\text {Glyco }}=\frac{G L U T 1_{g}}{\left(G L U T 1_{g}+G L U T 1_{N g}\right)},
$$

where $G L U T 1_{g}=$ the abundance of GLUT1 at 55 kDa representing glycosylated GLUT1 and $G L U T 1_{N o}$ $=$ the abundance of GLUT1 between 34 and $43 \mathrm{kDa}$ representing the nonglycosylated form. The (GLUT1 $\left.+G L U T 1_{N g}\right)$ is total abundance corresponding to $G L U T 1_{M}+G L U T 1_{C}$ in [Eq. 1]. The isotope enrichment $(E)$ of free precursor (glucose) pool $\left(E_{\text {Glu-free }}\right)$ in MTS was calculated by using the equation below.

$$
E_{\text {Glu-free }}=\left(\frac{13 C_{G l u}}{12 C_{G l u}+13 C_{\text {Glu }}}\right) \times 100,
$$

where $12 C_{G l u}=$ the abundance of free unlabeled glucose, and $13 C_{G l u}=$ the abundance of free ${ }^{13} \mathrm{C}$-labeled glucose in tissue homogenate. The enrichment of sugar moieties bound to lactose retained in MTS ( $\left.E_{\text {Lactose-bound (T) }}\right)$, lactose secreted into the media $\left(E_{\text {Lactose-bound }(M)}\right)$, and total lactose including lactose in MTS and media $\left(E_{\text {Lactose-bound }(T \& M)}\right)$ were calculated by using following equation:

$$
\begin{aligned}
& E_{\text {Lactose-bound }(i)} \\
& =\left(\frac{13 C_{\text {Lactose-single }(i)}+\left[13 C_{\text {Lactose-double }(i)} \times 2\right]}{\left[12 C_{\text {Lactose }(i)}+13 C_{\text {Lactose-single }(i)}+13 C_{\text {Lactose-double }(i)}\right] \times 2}\right) \\
& \times 100,
\end{aligned}
$$

where $12 C_{\text {Lactose }(i)}, 13 C_{\text {Lactose-single(i) }}$, and $13 C_{\text {Lactose-double }(i)}$ $=$ the abundance of unlabeled lactose, single moietylabeled lactose, and double moiety-labeled lactose, respectively in $i$ th lactose pool $[i=$ tissue $(T)$, medium $(M)$, or total $(T E \mathcal{G} M)]$. The $E_{\text {Glu-free }}$ (precursor enrichment) and $E_{\text {Lactose-bound(T\&M) }}$ (product enrichment) were used then to calculate fractional rate of lactose synthesis (FSR) during $3 \mathrm{~h}$ incubation period by using the following equation adopted from the equation used to calculate fractional rate of proteins synthesis in MTS in Appuhamy et al. (2011):

$$
F S R=\left(\frac{E_{\text {Lactose-bound }(T \& M)}}{E_{\text {Glu-free }} \times 3 \hbar}\right) \times 100 .
$$

\section{Statistical Analysis}

Treatment effects on the abundance of GLUT1 and other proteins, $D_{\text {Glyco }}, D_{\text {Trans }}$, and glucose uptake of BMEC were analyzed with the MIXED procedure in SAS (SAS Institute Inc.) by using the following model.

$$
\mathrm{Y}_{\mathrm{ijk}}=\mu+\mathrm{T}_{\mathrm{i}}+\mathrm{P}_{\mathrm{j}}+\mathrm{e}_{\mathrm{ijk}} \text {, }
$$




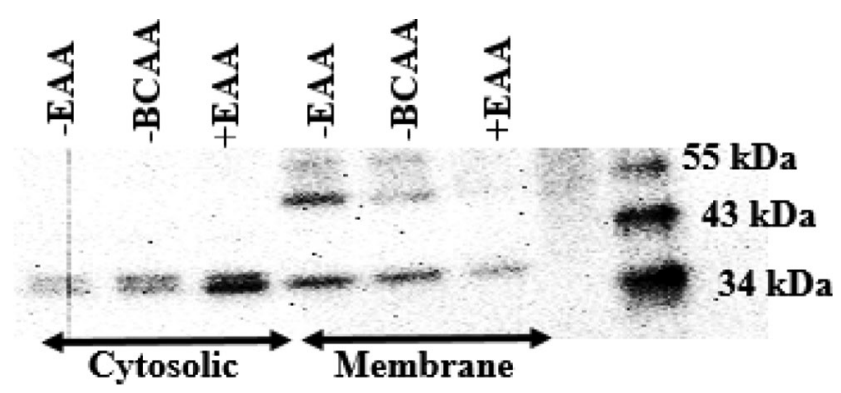

A

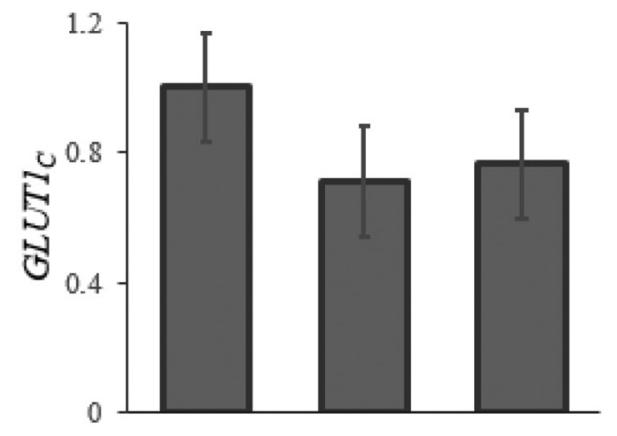

C

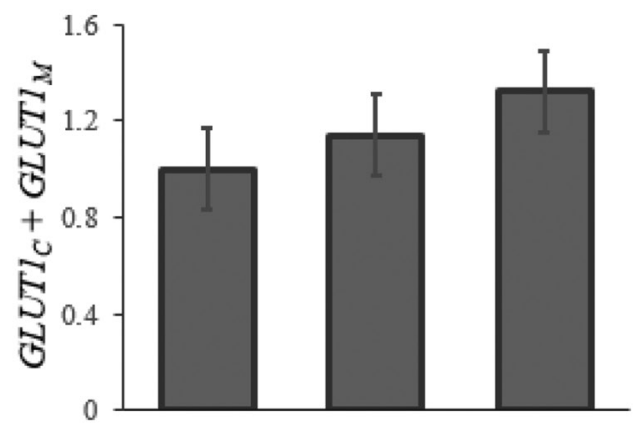

E

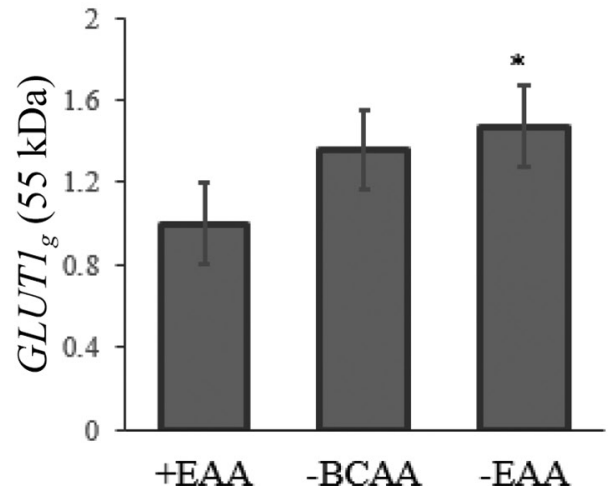

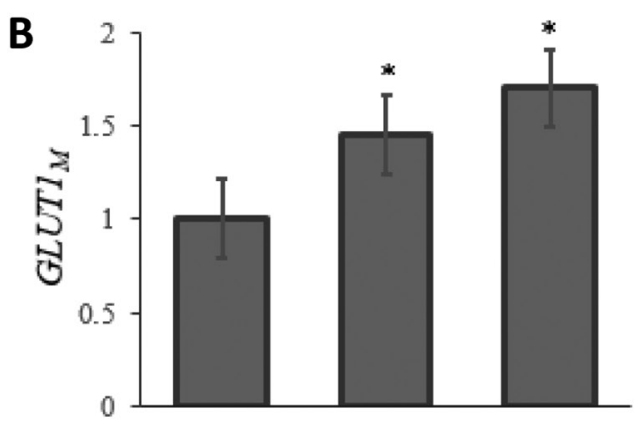

D

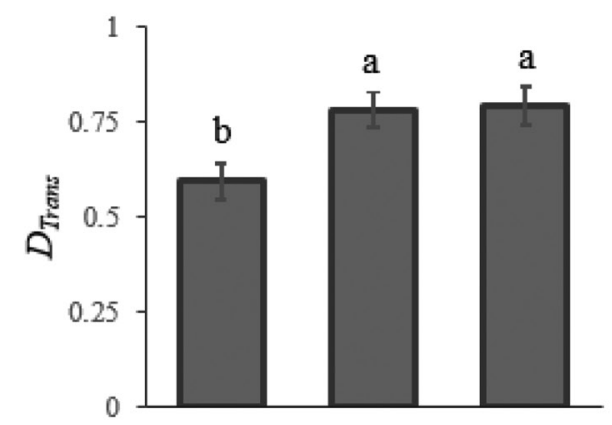

$\mathbf{F}$

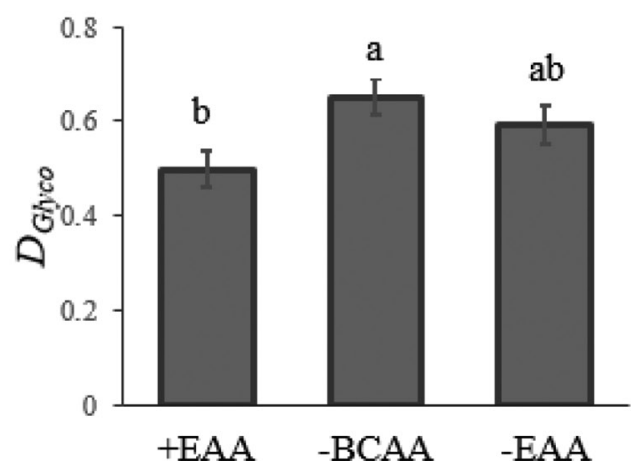

Figure 2. Effects of total branched-chain AA (-BCAA) or EAA (-EAA) deficiency in regular Dulbecco's Modified Eagle Medium with Ham's F12 medium (+EAA) on the abundance of GLUT1 in the cytosol $\left(G L U T 1_{C}, \mathrm{~A}\right)$, the cell membrane $\left(G L U T 1_{M}\right.$, B), the cytosol plus the membrane $\left(G L U T 1_{C}+G L U T 1_{M}, \mathrm{C}\right)$, the degree of translocation to the membrane $\left(D_{\text {Trans }}, \mathrm{D}\right)$, the abundance of glycosylated GLUT1 (E), and the degree of glycosylation $\left(D_{\text {Glyco }}, \mathrm{F}\right)$ in bovine mammary epithelial cells incubated in treatment medium for $24 \mathrm{~h}(\mathrm{n}=4)$. The abundances are normalized to that of +EAA. Different letters $(\mathrm{a}, \mathrm{b})$ indicate differences at $P<0.05$, whereas $*$ indicates tendencies $(0.05 \leq P<0.10)$ to be different from +EAA. The error bars represent SEM. The image above the panels presents a western blot of GLUT1 in cytosolic and membrane protein fractions along with a relevant portion of the protein marker ladder. 
where $\mathrm{Y}_{\mathrm{ijk}}=$ the response, $\mu=$ overall mean, $\mathrm{T}_{\mathrm{i}}=$ fixed effect of treatment, $\mathrm{P}_{\mathrm{j}}=$ random effect of cell passage, and $\mathrm{e}_{\mathrm{ijk}}=$ the random error $\left[\sim N\left(0, \mathrm{I} \sigma^{2}\right)\right]$. Similar mixed-effect model including fixed effect of treatment and random effect of cow was used in analyzing the treatment effects on the enrichments and FSR of MTS. The differences among the least squares means were determined with Tukey Kramer test. Statistical differences were declared at $P<0.05$, and a tendency toward significance was considered at $0.05 \leq P<0.10$.

\section{RESULTS AND DISCUSSION}

\section{Effects of BCAA on GLUT1 in BMEC}

Glucose transporter GLUT1 is a predominant cell membrane transporter found in cow mammary glands (Zhao, 2014). The abundance in the membrane represents a significant portion of overall activity of a cell membrane transporter and is primarily a function of the gene expression, cellular localization, and protein stability (e.g., the half-life). N-Glycosylation, an important posttranslational modification of GLUT1, enhances translocation from cytosol to the cell membrane, stability, and affinity to glucose (Asano et al., 1993; Yu et al., 2013). In the present study, we investigated effects of EAA, particularly the BCAA, availability to BMEC on the abundance of GLUT1 in cytosolic $\left(G L U T 1_{C}\right)$ and membrane proteins $\left(G L U T 1_{M}\right)$ harvested from BMEC cultured in media deficient in all EAA or only BCAA. The ratio between $G L U T 1_{M}$ and the total abundance $\left(G L U T 1_{M}+G L U T 1_{C}\right)$ was used to describe the degree of translocation of GLUT1 from cytosol to the cell membrane $\left(D_{\text {Trans }}\right)$. The results are presented in Figure 2. The $\operatorname{GLUT1}_{C}(P=0.411$, Figure $2 \mathrm{~A})$ or the total abundance $(P=0.585$, Figure $2 \mathrm{C})$ were not affected by treatments but $-\mathrm{BCAA}$ and $-\mathrm{EAA}$ tended to increase $G L U T 1_{M}$ compared with that of + EAA (Figure $2 \mathrm{~B})$. The deficiency of only BCAA $(P=041)$ or all EAA $(P=0.034)$ increased $D_{\text {Trans }}$ to a similar extent, which was $32 \%$ greater than that of $+\mathrm{EAA}$ (Figure 2D), suggesting a specific involvement of BCAA among all EAA in regulating the translocation of GLUT1 from cytosol to the cell membrane. Moreover, the enhanced $G L U T 1_{M}$ and $D_{\text {Trans }}$ for - BCAA indicates an elevated need for glucose, when BCAA supply to BMEC was limiting. The mammary glands take up BCAA in excess amounts compared with the amounts required for milk protein synthesis (Clark, 1975; Trottier et al., 1997) and, for instance, $25 \%$ of Leu taken into the glands is oxidized for energy (Bequette et al., 1996). Furthermore, Appuhamy et al. (2014) observed a 36\% decline in intracellular ATP concentration of BMEC when the media was deprived of all EAA. The authors also observed a significant activation (phosphorylation) of AMP-activated protein kinase (AMPK), which enhances the externalization of GLUT1 in other cell types (Wu et al., 2013).

The abundance of glycosylated GLUT1 (GLUT1g) and the ratio between GLUT1g and total GLUT1 indicating the degree of glycosylation $\left(D_{\text {Glyco }}\right)$ are given in Figure $2 \mathrm{E}$ and $2 \mathrm{~F}$, respectively. Total EAA deficiency tended to increase GLUT1g relative to +EAA $(P=$ 0.058 , Figure $2 \mathrm{E})$. On the other hand, $-\mathrm{BCAA}$ significantly increased $D_{\text {Glyco }}$ by $35 \%$ relative to + EAA ( $P=$ 0.031 , Figure 2F). Moreover, it was evident that the glycosylated form of GLUT1 ( $55 \mathrm{kDa}$ ) was limited to the cell membrane, whereas the nonglycosylated (34-43 $\mathrm{kDa}$ ) form was found in both the cell membrane and cytosol (WB image in Figure 2). Asano et al. (1991) made similar observations in Chinese hamster ovary cells. Moreover, Asano et al. (1991, 1993) demonstrated glycosylation of GLUT1 was related positively to the half-life of GLUT1 and GLUT1's affinity to glucose. Overall, BCAA deficiency increased the abundance of GLUT1 in the cell membrane by enhancing glycosylation and thus translocation of GLUT1 from cytosol to the cell membrane in BMEC.

The effects of individual BCAA deficiencies on the abundances of GLUT1, $D_{\text {Trans }}$, and $D_{\text {Glyco }}$ are presented in Figure 3. The BMEC grown in media deficient in Leu or Ile had lower $G L U T 1_{C}$ than did +EAA $(P<$ 0.050 , Figure $3 \mathrm{~A})$. The lower $G L U T 1_{C}$ of - Leu was a result of more GLUT1 being translocated to the membrane as the Leu deficiency tended to have a greater $\operatorname{GLUT1}_{M}(P=0.074)$ than did +EAA (Figure 3B), while total GLUT1 abundance remained unchanged relative to + EAA $(P=0.596$, Figure 3C). Consistently, the ratio between $G L U T 1_{M}$ and total GLUT1 indicative of the degree of translocation tended to increase by $44 \%$ for - Leu $(P=0.059$, Figure $4 \mathrm{D})$. On the other hand, -Ile tended to have a lower abundance of total GLUT1 than did +EAA $(P=0.071$, Figure $3 \mathrm{C})$, whereas both treatments had similar $G L U T 1_{M}(P$ $=0.953)$ to suggest that the lower $G L U T 1_{C}$ of - Ile was a result of lower GLUT1 expression. The -Ile can be associated with a reduced expression of GLUT1 by decreasing mammalian target of rapamycin (mTOR) activity shown to stimulate protein synthesis in BMEC (Buller et al., 2008; Appuhamy et al., 2012). However, how -Ile would uniquely decrease the expression of GLUT1 is not clear as - Leu has also been shown to decrease mTOR activity in BMEC (Appuhamy et al., 2012). The abundance of glycosylated GLUT1 at 55 $\mathrm{kDa}$ was not affected by - Leu $(P=0.127)$ or - Ile $(P$ $=0.910$, Figure 3E). Only - Leu, however, tended to increase $D_{\text {Glyco }}$ by $43 \%(P=0.072$, Figure $3 \mathrm{~F})$. The Val deficiency did not affect any of those parameters 
of GLUT1 in BMEC (Figure 3, $P>0.510$ ). Overall, -Leu tended to stimulate both glycosylation and the abundance of GLUT1 in the cell membrane.

\section{Effects of BCAA on Glucose Uptake of BMEC}

Because glucose requirement is substantially greater in lactating versus nonlactating cows and up to $85 \%$ of plasma glucose supply to the mammary glands is utilized for lactose synthesis during lactation (Annison and Linzell, 1964; Zhao, 2014), glucose uptake of mammary epithelial cells can be rate-limiting for lactose synthesis (Kronfeld, 1982). We determined glucose uptake of BMEC by measuring the depletion of medium glucose during a specific duration of incubation. Figure 4A presents glucose uptake of BMEC incubated in +EAA, - Leu, or - Ile media for $3.0 \mathrm{~h}$. The - Val was not included in this experiment because of insignificant effects in previous experiments. As mentioned above, we chose the $3.0 \mathrm{~h}$ incubation to compare the glucose uptake response of BMEC with that of MTS. The glucose uptake increased by $40 \%$ for - Leu $(P=0.030)$ but did not respond to - Ile $(P=0.812)$ compared with + EAA (Figure 4A). These results are consistent with $D_{\text {Trans }}$ and $D_{\text {Glyco }}$ of -Leu and -Ile, however, measured after a 24-h incubation (Figure 3), suggesting that the increased glucose uptake could be a result of an increment in cell membrane GLUT1 activity. Considering together, we speculate that enhancements in $D_{\text {Trans }}$ and $D_{\text {Glyco }}$ for - Leu could be quicker than $24 \mathrm{~h}$. Figure $4 \mathrm{~B}$ shows how glucose concentration in media changed when BMEC were cultured with graded concentrations of Leu in media $(0.2,0.4$, and $2.0 \mathrm{mM})$ for $24 \mathrm{~h}$. Within the first hour of incubation, glucose concentrations in media with 0.2 or $0.4 \mathrm{~m} M$ Leu depleted sharply $(P<$ 0.050), whereas glucose concentration in media with 2.0 $\mathrm{m} M$ Leu remained unchanged. Consequently, the glucose uptake of 0.2 and $0.4 \mathrm{mM}$ Leu were significantly greater than that of $2.0 \mathrm{mM}$ Leu during the first hour (Figure 4C). The rates of extracellular glucose depletion and thus glucose uptake of 0.2 and $0.4 \mathrm{~m} M$ Leu were, however, slower during the rest of the incubation period (1-24 h). The accelerated glucose uptake during the first hour could be a compensatory response to glucose starvation performed before the incubation. The cells in 0.2 and $0.4 \mathrm{mM}$ Leu continued to be associated with greater glucose uptake compared with those in 2.0 $\mathrm{m} M$ Leu until $12 \mathrm{~h}(P<0.050$, Figure $4 \mathrm{C})$. Glucose concentration of $2.0 \mathrm{~m} M$ Leu, however, decreased more sharply $(P=0.006$, Figure $4 \mathrm{~B})$ and had greater glucose uptake than did 0.2 and $0.4 \mathrm{~m} M$ Leu $(P<0.015$, Figure 4C) during the last $12 \mathrm{~h}$. We assume that this delayed glucose uptake response to $2.0 \mathrm{mM}$ Leu could be a result of a time requirement for catabolism and thus depletion of intracellular Leu possibly elevated in response to high extracellular Leu. Previous studies have shown that increased intracellular BCAA could decrease glucose uptake (Li et al., 2017).

\section{Effects of BCAA on the Abundance of Enzymes in Lactose Synthesis Pathway}

Table 2 gives the effects of extracellular BCAA or total EAA deficiency on the abundance of some key enzymes regulating lactose biosynthesis (Kuhn et al., 1980). The protein abundances are from the proteomic analysis described above. Hexokinase (HK) catalyzes the conversion of glucose into glucose-6-phosphate, representing the first reaction of the pathway through which UDP-galactose is derived from glucose. Xiao and Cant (2005) demonstrated HK had much greater control over lactose synthesis rates than do glucose transporters in BMEC. The abundance of HK tended to increase for -BCAA $(P=0.065$, Table 2). Phosphoglucomutase and UDP-glucose pyrophosphorylase catalyze the next 2 reactions converting glucose-6-phosphate to UDP-glucose, which will be eventually epimerized to produce UDP-galactose by UDP-glucose-4-epimerase. Branched-chain amino acid deficiency or -EAA did not change the abundance of any of those enzymes $(P$ $>0.120$ ). Galactokinase and galactose-1-phosphate uridyltransferase are key enzymes catalyzing reactions that generate UDP-galactose from extracellular galactose (Twarog and Larson, 1964). Because the majority of UDP-galactose is synthesized using glucose, the significance of those enzymes in lactose synthesis is minimal. Nonetheless, $-\mathrm{BCAA}$ did not affect the abundance of any of those enzymes $(P>0.610)$. On the other hand, -EAA was associated with a lower abundance of galactose-1-phosphate uridyltransferase $(P=0.028) . \beta-1,4$-galactosyltransferase and $\alpha$-LA are 2 important proteins forming lactase synthase that catalyzes the galactosylation of glucose to produce lactose in the Golgi apparatus (Kuhn et al., 1980). Because the present proteomic analysis was performed on cytosolic proteins, $\beta$-1,4-galactosyltransferase and $\alpha$-LA were not detected. Nonetheless, when considered together, the results of WB and proteomic analyses suggest that the deficiency of BCAA, most probably Leu can enhance glucose uptake and utilization of glucose for lactose synthesis by increasing the abundance of GLUT1 and HK in BMEC.

\section{Effects of BCAA on Lactose Synthesis Rates in MTS}

Mammary tissue slices from lactating cows were used for determining lactose synthesis rates as slices are more representative of the events occurring in vivo and 


\section{Cytosolic}

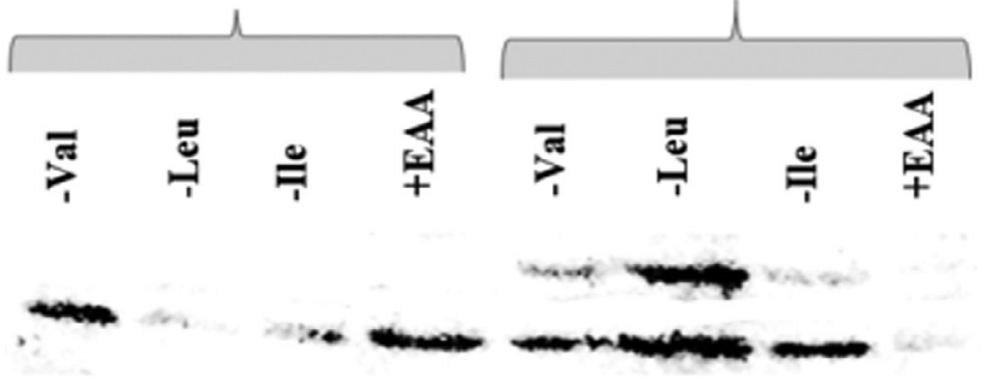

Membrane

\section{$55 \mathrm{kDa}$}

34-43 kDa
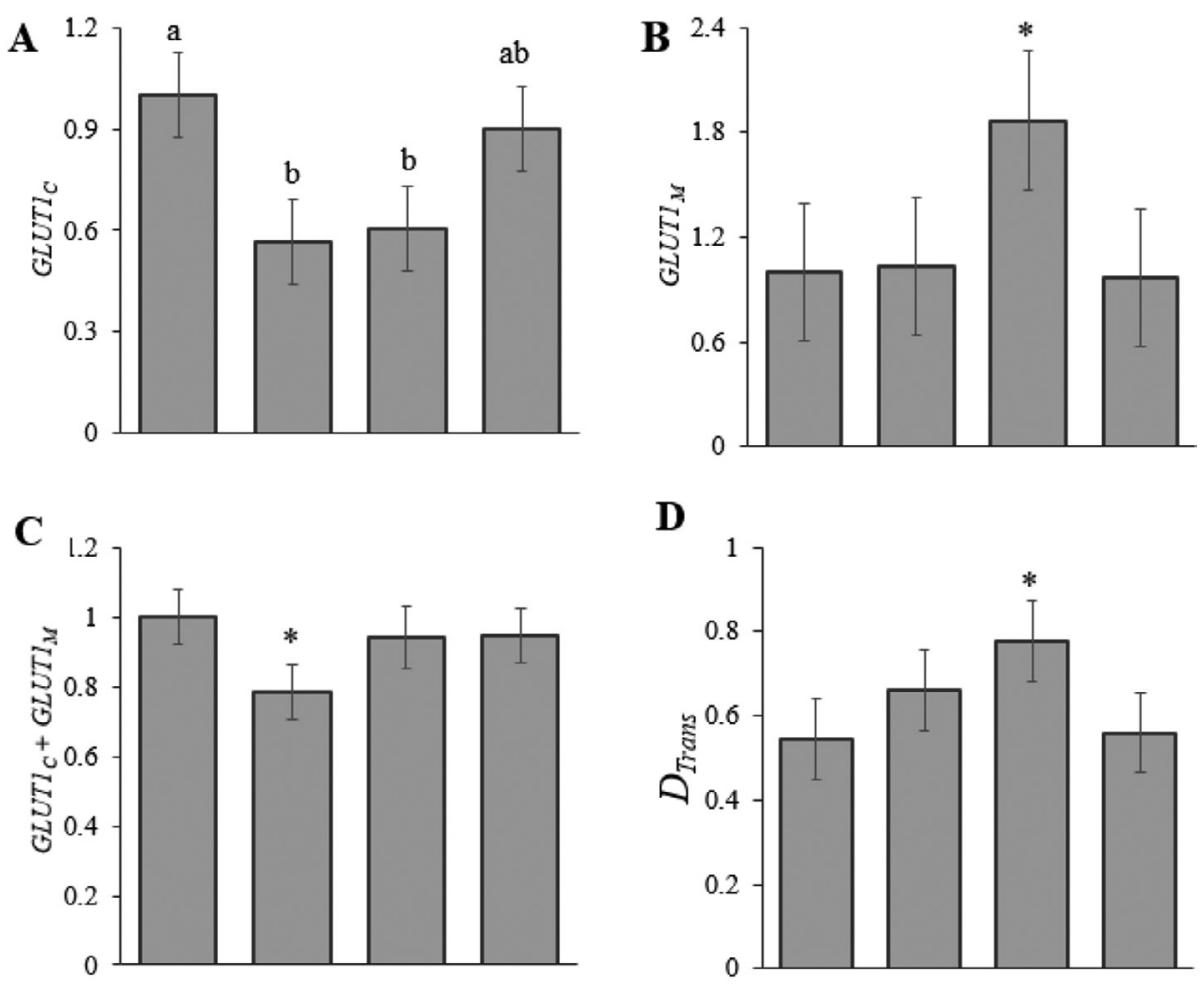

D
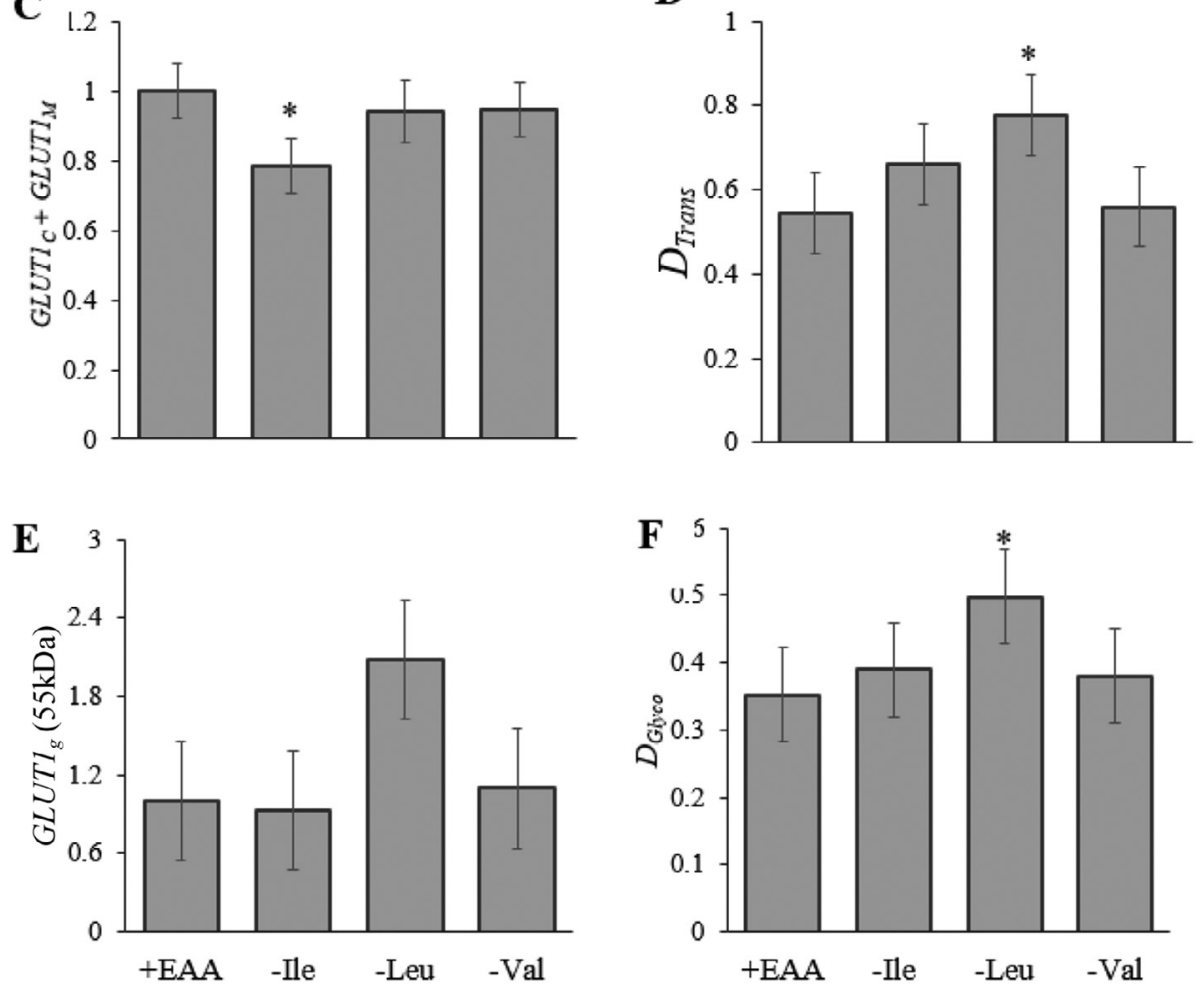

Figure 3. Effects of only Ile (-Ile), Leu (-Leu), or Val (-Val) deficiency in regular Dulbecco's Modified Eagle Medium with Ham's F12 medium (+EAA) on the abundance of GLUT1 in the cytosol $\left(G L U T 1_{C}, \mathrm{~A}\right)$, the cell membrane $\left(G L U T 1_{M}\right.$, B), the cytosol plus the membrane $\left(G L U T 1_{C}+G L U T 1_{M}, \mathrm{C}\right)$, the degree of translocation of GLUT1 to the membrane $\left(D_{\text {Trans }}, \mathrm{D}\right)$, the abundance of glycosylated GLUT1 (E), and the degree of glycosylation $\left(D_{G l y c o}, \mathrm{~F}\right)$ in bovine mammary epithelial cells $(\mathrm{n}=4)$. The abundances are normalized to that of + EAA. Different letters $(\mathrm{a}, \mathrm{b})$ indicate differences of the means at $P<0.05$, whereas $*$ indicates tendencies $(0.05 \leq P<0.10)$ to be different from + EAA. The error bars represent SEM. The image above panels presents a western blot of GLUT1 in cytosolic and membrane protein fractions. 
A

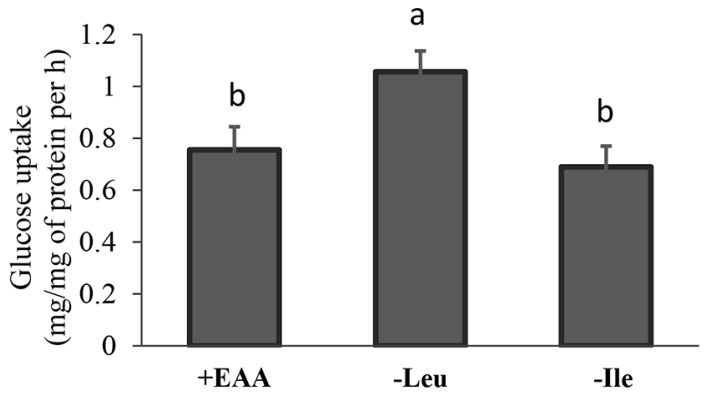

B

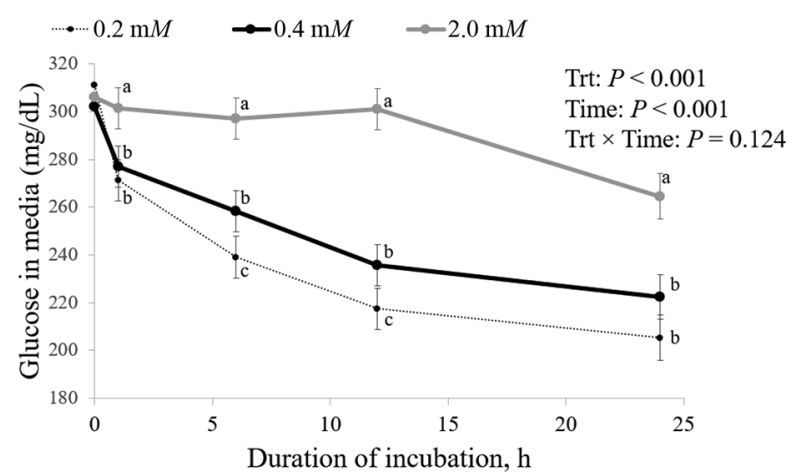

C

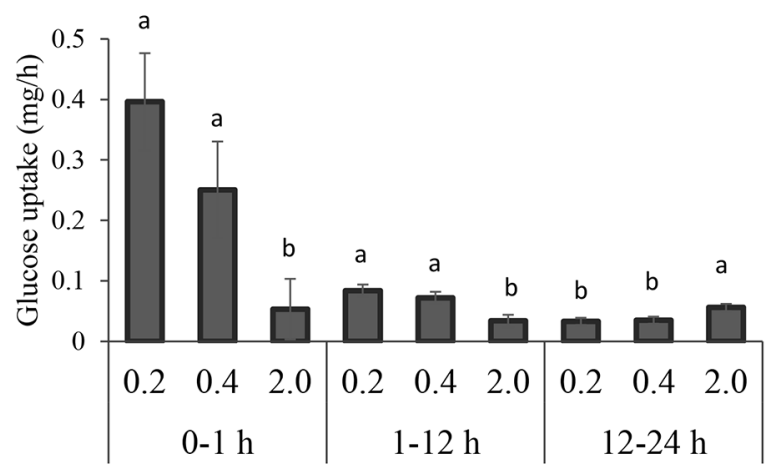

Figure 4. Effects of Ile (-Ile) or Leu (- Leu) deficiency in regular Dulbecco's Modified Eagle Medium with Ham's F12 (DMEM/F12) medium (+EAA) on glucose uptake of bovine mammary epithelial cells (BMEC) incubated in treatment medium $(\mathrm{n}=5)$ for $3 \mathrm{~h}(\mathrm{~A})$. Different letters $(\mathrm{a}, \mathrm{b})$ indicate significantly different $(P<0.05)$ treatment means. Effects of Leu at $0.2,0.4$, and $2.0 \mathrm{mM}$ concentrations in DMEM/F12 medium on glucose concentration in media (B) and glucose uptake of BMEC incubated in the media $(\mathrm{n}=5)$ for $24 \mathrm{~h}$ (C). Different letters $(\mathrm{a}, \mathrm{b})$ at each time point $(\mathrm{B})$ or within each time interval $(\mathrm{C})$ indicate differences at $P<0.05$. The error bars in $\mathrm{A}, \mathrm{B}$, and $\mathrm{C}$ represent SEM.

likely produce greater amounts of lactose per experimental unit compared with mammary epithelial cells. The 3-h incubation with isotope-labeled glucose was employed as Bartley et al. (1966) was able to explain lactose synthesis in rat MTS using ${ }^{14} \mathrm{C}$-labeled glucose in similar manner. Similar to what was observed with BMEC incubated for the same duration, $-\mathrm{Leu}_{\mathrm{p}}$ was related to a $50 \%$ increase in glucose uptake $(P=0.057$, Figure 5). Based on this persistent response and the fact that GLUT1 is a major glucose transporter in lactating
Table 2. Effects of total branched-chain AA (-BCAA) or total EAA (-EAA) deficiency in regular Dulbecco's Modified Eagle Medium with Ham's F12 medium (+EAA) on the abundance of some important enzymes in lactose synthesis pathway in bovine mammary epithelial cells incubated in treatment media for $24 \mathrm{~h}(\mathrm{n}=4)$

\begin{tabular}{|c|c|c|c|c|c|}
\hline \multirow[b]{2}{*}{ Enzyme } & \multicolumn{3}{|c|}{ LSM } & \multirow[b]{2}{*}{ SEM } & \multirow[b]{2}{*}{$P$-value } \\
\hline & $+\mathrm{EAA}$ & -BCAA & $-\mathrm{EAA}$ & & \\
\hline Hexokinase & 1.00 & $1.75^{*}$ & 1.56 & 0.20 & 0.064 \\
\hline Phosphoglucomutase & 1.00 & 0.88 & 0.76 & 0.14 & 0.150 \\
\hline $\begin{array}{l}\text { UDP-glucose } \\
\text { pyrophosphorylase }\end{array}$ & 1.00 & 1.06 & 1.41 & 0.13 & 0.136 \\
\hline Galactose-4-epimerase & 1.00 & 0.78 & 0.63 & 0.12 & 0.121 \\
\hline Galactokinase & 1.00 & 1.14 & 1.05 & 0.16 & 0.378 \\
\hline $\begin{array}{l}\text { Galactose-1-phosphate } \\
\text { uridyltrasferase }\end{array}$ & $1.00^{\mathrm{b}}$ & $1.05^{\mathrm{b}}$ & $1.18^{\mathrm{a}}$ & 0.07 & 0.030 \\
\hline
\end{tabular}

${ }^{\mathrm{a}, \mathrm{b}}$ Different superscripts in a given row indicate significant differences among treatments $(P<0.05)$.

*Indicates tendencies to be different from + EAA $(0.05 \leq P<0.10)$.

mammary tissues (Zhao and Keating, 2007; Zhang et al., 2018), we speculate again that potential increments in GLUT1 activity for -Leu (e.g., increased $D_{\text {Trans }}$ or $D_{\text {Glyco }}$ ) observed with BMEC could be quicker than 24 h. On the other hand, the removal of all 3 BCAA from media did not change glucose uptake of MTS (Figure $5)$ even though it was associated with increased $D_{\text {Trans }}$ and $D_{\text {Glyco }}$ in BMEC (Figure 2). Perhaps, the regulation of GLUT1 by BCAA is more complex and requires a longer time to exert an effect than that of Leu alone. It is also noteworthy that the BCAA concentrations of treatment media were different between BMEC and MTS experiments. Some part of the discrepancies in

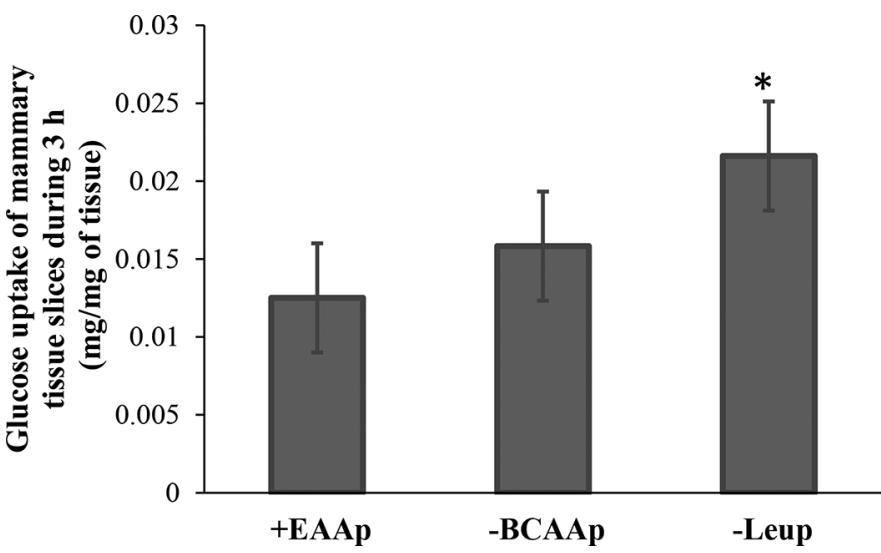

Figure 5. Effects of deprivation of all branched-chain AA (BCAAp) or only Leu (-Leup) from Dulbecco's Modified Eagle Medium with Ham's F12 medium containing EAA and glucose at concentrations similar to plasma concentrations of dairy cows (+EAA) on glucose uptake of mammary tissue slices $(\mathrm{n}=6)$ incubated in treatment media for $3 \mathrm{~h}$. The glucose uptake was determined measuring the depletion of glucose in media during the 3-h incubation period. *Tendency to be different from + EAAp $(P=0.057)$. Error bars represent SEM. 
observed responses could stem from those differences as well.

Table 3 gives ${ }^{13} \mathrm{C}$ enrichment of the precursor and product pools and FSR of lactose for MTS cultured in DMEM/F12 medium with all EAA at physiological concentrations $\left(+\mathrm{EAA}_{\mathrm{p}}\right)$ and $+\mathrm{EAA}_{\mathrm{p}}$ deprived of all 3 BCAA $\left(-\right.$ BCAA $\left._{p}\right)$ or only Leu $\left(-\right.$ Leu $\left._{p}\right)$. Even though both glucose and galactose (UDP-galactose) pools in MTS should have represented the total precursor pool for lactose synthesis, ${ }^{13} \mathrm{C}$ enrichment of intracellular free glucose $\left(E_{\text {Glu-free }}\right.$, equation 3$)$ pool alone was used as the total precursor enrichment considering the fact that $85 \%$ of the hexoses in lactose is derived from glucose (Bickerstaffe et al., 1974) and chromatographic separation of nucleotide sugars is rather challenging (Kuhn et al., 1980; Räbinä et al., 2001; Pabst et al., 2010). Nonetheless, deprivation of all BCAA or only Leu did not affect $E_{\text {Glu-free }}$ in MTS $(P=0.755)$. Considering the enhanced glucose uptake of MTS for $-\mathrm{Leu}_{\mathrm{p}}$ (Figure 5 ) that was also in line with -Leu of BMEC (Figure $4 \mathrm{~A}$ ), one would expect an elevated $E_{G l u-f r e e}$ for $-\mathrm{Leu}_{\mathrm{p}}$. However, $E_{\text {Glu-free }}$ is not only a function of ${ }^{13} \mathrm{C}$-glucose uptake but also responds to changes in the unlabeled free glucose pool that was endogenous to MTS. Even though the underlying mechanisms are not clear, an increase in the unlabeled glucose pool could presumably cause $E_{\text {Glu-free }}$ to remain unchanged for $-\mathrm{Leu}_{\mathrm{p}}$. Moreover, such increment in the unlabeled glucose pool seems to be specific to the deprivation of Leu alone as $-\mathrm{BCAA}_{\mathrm{p}}$ not affecting ${ }^{13} \mathrm{C}$-glucose uptake also had similar $E_{G l u-\text { free }}$ relative to $+\mathrm{EAA}_{\mathrm{p}}$. The ${ }^{13} \mathrm{C}$-enrichment of lactose retained in MTS [ $\left.E_{\text {Lactose-bound (T) }}\right]$, lactose secreted into the medium $\left[E_{\text {Lactose-bound }(M)}\right]$, and total lactose $\left[E_{\text {Lactose-bound }(T B M M)}\right]$ decreased by $26(P=0.052), 33(P=$ $0.022)$, and $27 \%(P=0.018)$, respectively, for $-\mathrm{BCAA}_{\mathrm{p}}$ (Table 3) indicating an impairment of incorporation of glucose into lactose as verified also by lower FSR of $-\mathrm{BCAA}$ relative to $+\mathrm{EAA}(1.75$ vs. $2.47 \% / \mathrm{h}, P=$ 0.021). Despite the improved glucose uptake (Figure 5), -Leu did not affect FSR $(P>0.797)$, suggesting that glucose uptake mediated by Leu or glucose uptake in general has a minimal effect on lactose synthesis rates. In agreement, Xiao and Cant (2005) demonstrated that glucose uptake had a weaker control over utilization of glucose for lactose synthesis than did the other reactions in lactose synthesis pathway in BMEC. The significantly decreased FSR for - BCAA while being not affected by -Leu highlights that the other BCAA, Ile, and Val alone or together with Leu could stimulate lactose synthesis independent of glucose uptake. In order for evaluating further the responses for BCAA deficiencies, we performed a meta-analysis (unpublished data) using the methodology described in Appuhamy et al. (2013) and data from in vivo studies published in Korhonen et al. (2002), Haque et al. (2012), and Tian et al. (2017). In those studies, lactose yields of dairy cows were measured in response to abomasal or intravenous infusions of a complete EAA mixture or the EAA mixtures devoid of individual BCAA. The results (unpublished data) demonstrated that removal of Ile from a complete EAA mixture decreased lactose yield $(P=0.046)$, whereas the removal of neither Leu nor Val affected it $(P>0.450)$. Consistently, an abomasal infusion of Ile (30.7 g/animal per d) increased milk yield and milk lactose yield of multiparous Holstein cows in Robinson et al. (1999).

In summary, extracellular Leu deficiency increased glucose uptake of BMEC possibly by enhancing the abundance and activity (e.g., glycosylation) of GLUT1 in the cell membrane. The deficiencies of Val or Ile did not affect GLUT1 or glucose uptake. The total BCAA deficiency tended to enhance the abundance of hexokinase that can join glucose transporters in regulating glucose uptake. Nonetheless, extracellular Leu deficiency and the associated increase in glucose uptake did not affect lactose synthesis rates in MTS. On the other hand, lactose synthesis rates decreased for extracellular total BCAA deficiency suggesting that (1) glucose uptake was not rate-limiting to lactose synthesis, and (2) the availability of Ile, Val, or both to MTS was more significantly involved in regulating lactose synthesis rates than the availability of Leu was. This study also highlights the importance of addressing the interactions

Table 3. Effects of extracellular branched-chain AA deprivations on $\mathrm{C}^{13}$ enrichments in precursor and product pools of lactose and fractional synthesis rates of lactose (FSR) of cow mammary tissue slices (MTS) incubated in treatment media for $3 \mathrm{~h}(\mathrm{n}=6)$

\begin{tabular}{lccccc}
\hline & \multicolumn{3}{c}{ Treatment $^{1}$} \\
\cline { 2 - 4 } Variable & + EAA $_{\mathrm{p}}$ & - Leu $_{\mathrm{p}}$ & - BCAA $_{\mathrm{p}}$ & SEM & P-value \\
\hline $\mathrm{C}^{13}$-enrichments, \% & & & & & \\
$E_{\text {Glu-free }}$ & 73.1 & 72.4 & 74.23 & 2.99 & 0.726 \\
$E_{\text {Lactose-bound (T) }}$ & 8.12 & 7.64 & 6.05 & 0.69 & 0.054 \\
$E_{\text {Lactose-bound (M) }}$ & 1.60 & 1.58 & 1.07 & 0.30 & 0.039 \\
$E_{\text {Lactose-bound (TBM) }}$ & 5.24 & 5.42 & 3.82 & 0.45 & 0.020 \\
FSR, \%/h & 2.42 & 2.47 & 1.75 & 0.20 & 0.029 \\
\hline
\end{tabular}

${ }^{1}+\mathrm{EAA}_{\mathrm{p}}=$ Dulbecco's Modified Eagle Medium with Ham's F12 medium containing EAA and glucose at concentrations similar to plasma concentrations of cows (Table 1 ); $-\mathrm{Leu}_{\mathrm{p}}=+\mathrm{EAA}_{\mathrm{p}}$ deprived of only Leu; $-\mathrm{BCAA}_{\mathrm{p}}=+\mathrm{EAA}_{\mathrm{p}}$ deprived of Leu, Ile, and Val.

${ }^{2} E_{\text {Glu-free }}=\mathrm{C}^{13}$-enrichment of intracellular free glucose pool of MTS, $E_{\text {Lactose-bound }(T)}=\mathrm{C}^{13}$-enrichment of glucose incorporated into lactose that was retained in MTS, $E_{\text {Lactose-bound }(M)}=\mathrm{C}^{13}$-enrichment of glucose incorporated into lactose that was secreted into the medium, and $E_{\text {Lactose-bound }(M)}=\mathrm{C}^{13}$-enrichment of glucose incorporated into total lactose (total lactose $=$ lactose retained in MTS + lactose secreted into the medium).

${ }^{3} \mathrm{FSR}=$ fractional synthesis rate of lactose, calculated by using $E_{G l u \text {-free }}$ (the precursor enrichment) and $E_{\text {Lactose-bound (TBM) }}$ (the product enrichment). 
between nutrients (e.g., energy and protein) in describing milk component synthesis in the mammary glands.

\section{ACKNOWLEDGMENTS}

Authors acknowledge the assistance received from staff in W. M. Keck Metabolomics Research Laboratory and the Protein Facility at Iowa State University (Ames, IA). The authors have not stated any conflicts of interest.

\section{REFERENCES}

Annison, E. F., and J. L. Linzell. 1964. The oxidation and utilization of glucose and acetate by the mammary gland of the goat in relation to their overall metabolism and to milk formation. J. Physiol. 175:372-385. https://doi.org/10.1113/jphysiol.1964.sp007522.

Appuhamy, J. A. D. R. N., A. L. Bell, W. A. D. Nayananjalie, J. Escobar, and M. D. Hanigan. 2011. Essential amino acids regulate both initiation and elongation of mRNA translation independent of insulin in MAC-T cells and bovine mammary tissue slices. J. Nutr. 141:1209-1215. https://doi.org/10.3945/jn.110.136143.

Appuhamy, J. A. D. R. N., W. A. Nayananjalie, E. M. England, D. E. Gerrard, R. M. Akers, and M. D. Hanigan. 2014. Effects of AMPactivated protein kinase (AMPK) signaling and essential amino acids on mammalian target of rapamycin (mTOR) signaling and protein synthesis rates in mammary cells. J. Dairy Sci. 97:419-429. https://doi.org/10.3168/jds.2013-7189.

Appuhamy, J. A. D. R. N., N. A. Knoebel, W. A. D. Nayananjalie, J. Escobar, and M. D. Hanigan. 2012. Isoleucine and leucine independently regulate mTOR signaling and protein synthesis in MAC$\mathrm{T}$ cells and bovine mammary tissue slices. J. Nutr. 142:484-491. https://doi.org/10.3945/jn.111.152595.

Appuhamy, J. A. D. R. N., A. B. Strathe, S. Jayasundara, C. Wagner-Riddle, J. Dijkstra, J. France, and E. Kebreab. 2013. Antimethanogenic effects of monensin in dairy and beef cattle: A meta analysis. J. Dairy Sci. 96:5161-5173. https://doi.org/10.3168/jds .2012-5923.

Arriola Apelo, S. I., L. M. Singer, X. Y. Lin, M. L. McGilliard, N. R. St-Pierre, and M. D. Hanigan. 2014. Isoleucine, leucine, methionine, and threonine effects on mammalian target of rapamycin signaling in mammary tissue. J. Dairy Sci. 97:1047-1056. https:// doi.org/10.3168/jds.2013-7348.

Asano, T., H. Katagiri, K. Takata, J. L. Lin, H. Ishihara, K. Inukai, K. Tsukuda, M. Kikuchi, H. Hirano, Y. Yazaki, and Y. Oka. 1991. The role of N-glycosylation of GLUT1 for glucose transport activity. J. Biol. Chem. 266:24632-24636. https://doi.org/10.1016/ S0021-9258(18)54276-9.

Asano, T., K. Takata, H. Katagiri, H. Ishihara, K. Inukai, M. Anai, H. Hirano, Y. Yazaki, and Y. Oka. 1993. The role of N-glycosylation in the targeting and stability of GLUT1 glucose transporter. FEBS Lett. 324:258-261. https://doi.org/10.1016/0014-5793(93)80129-I.

Bartley, J. C., S. Abraham, and I. L. Chaikoff. 1966. Biosynthesis of lactose by mammary gland slices from the lactating rat. J. Biol. Chem. 241:1132-1137. https://doi.org/10.1016/S0021 -9258(18)96812-2.

Bequette, B. J., F. R. C. Backwell, J. C. MacRae, G. E. Lobley, L. A. Crompton, J. A. Metcalf, and J. D. Sutton. 1996. Effect of intravenous amino acid infusion on leucine oxidation across the mammary gland of the lactating goat. J. Dairy Sci. 79:2217-2224. https://doi .org/10.3168/jds.S0022-0302(96)76598-0.

Bickerstaffe, R., E. F. Annison, and J. L. Linzell. 1974. The metabolism of glucose, acetate, lipids and amino acids in lactating dairy cows. J. Agric. Sci. 82:71-85. https://doi.org/10.1017/ S0021859600050243.

Buller, C. L., R. D. Loberg, M. H. Fan, Q. Zhu, J. L. Park, E. Vesely, K. Inoki, K. L. Guan, and F. C. Brosius 3rd.. 2008. A GSK-3/
TSC2/mTOR pathway regulates glucose uptake and GLUT1 glucose transporter expression. Am. J. Physiol. Cell Physiol. 295:C836-C843. https://doi.org/10.1152/ajpcell.00554.2007.

Chen, M., M. Shen, Y. Li, C. Liu, K. Zhou, W. Hu, B. Xu, Y. Xia, and W. Tang. 2015. GC-MS-based metabolomic analysis of human papillary thyroid carcinoma tissue. Int. J. Mol. Med. 36:1607-1614. https://doi.org/10.3892/ijmm.2015.2368.

Clark, J. H. 1975. Lactational responses to post ruminal administration of proteins and amino acids. J. Dairy Sci. 58:1178-1197. https: //doi.org/10.3168/jds.S0022-0302(75)84696-0.

Clark, J. H., H. R. Spires, R. G. Derrig, and M. R. Bennink. 1977. Milk production, nitrogen utilization and glucose synthesis in lactating cows infused postruminally with sodium caseinate and glucose. J. Nutr. 107:631-644. https://doi.org/10.1093/jn/107.4.631.

Curtis, R. V., J. J. M. Kim, J. Doelman, and J. P. Cant. 2018. Maintenance of plasma branched-chain amino acid concentrations during glucose infusion directs essential amino acids to extra-mammary tissues in lactating dairy cows. J. Dairy Sci. 101:4542-4553. https: //doi.org/10.3168/jds.2017-13236.

Duhlmeier, R., A. Hacker, A. Widdel, W. von Engelhardt, and H. P. Sallmann. 2005. Mechanisms of insulin-dependent glucose transport into porcine and bovine skeletal muscle. Am. J. Physiol Regul. Integr. Comp. Physiol. 289:R187-R197. https://doi.org/10 .1152 /ajpregu.00502.2004.

Ganesan, S., J. V. V. Silva, C. A. Kaya, H. K. J. P. Wickramasinghe, and J. A. D. R. N. Appuhamy. 2019. Effects of extracellular branched-chain amino acid availability on proteins regulating fat synthesis in bovine mammary cells; a proteomics analysis. J. Dairy Sci. 102(Suppl.1):342 (Abstr.).

Haque, M. N., H. Rulquin, A. Andrade, P. Faverdin, J. L. Peyraud, and S. Lemosquet. 2012. Milk protein synthesis in response to the provision of an "ideal" amino acid profile at 2 levels of metabolizable protein supply in dairy cows. J. Dairy Sci. 95:5876-5887. https://doi.org/10.3168/jds.2011-5230.

Hu, H., J. Wang, D. Bu, H. Wei, L. Zhou, F. Li, and J. J. Loor. 2009. In vitro culture and characterization of a mammary epithelial cell line from Chinese Holstein dairy cow. PLoS One 4:e7636. https:// doi.org/10.1371/journal.pone.0007636.

Hunter, G. D., and G. C. Millson. 1964. Gluconeogenesis in the lactating dairy cow. Res. Vet. Sci. 5:1-6. https://doi.org/10.1016/S0034 $-5288(18) 34819-7$

Huntington, G. B., D. L. Harmon, and C. J. Richards. 2006. Sites, rates, and limits of starch digestion and glucose metabolism in growing cattle. J. Anim. Sci. 84(suppl_13):E14-E24. https://doi .org $/ 10.2527 / 2006.8413$ supplE14x.

Ip, C., and T. L. Dao. 1978. Effect of estradiol and prolactin on galactosyltransferase and alpha-lactalbumin activities in rat mammary gland and mammary tumor. Cancer Res. 38:2077-2083.

Kim, H. Y., K. M. Lee, S. H. Kim, Y. J. Kwon, Y. J. Chun, and H. K. Choi. 2016. Comparative metabolic and lipidomic profiling of human breast cancer cells with different metastatic potentials. Oncotarget 7:67111-67128. https://doi.org/10.18632/oncotarget.11560.

Komatsu, T., F. Itoh, S. Kushibiki, and K. Hodate. 2005. Changes in gene expression of glucose transporters in lactating and nonlactating cows. J. Anim. Sci. 83:557-564. https://doi.org/10.2527/2005 $.833557 \mathrm{x}$.

Korhonen, M., A. Vanhatalo, and P. Huhtanen. 2002. Evaluation of isoleucine, leucine, and valine as a second-limiting amino acid for milk production in dairy cows fed grass silage diet. J. Dairy Sci. 85:1533-1545. https://doi.org/10.3168/jds.S0022-0302(02)74223 $-9$.

Kronfeld, D. S. 1982. Major metabolic determinants of milk volume, mammary efficiency, and spontaneous ketosis in dairy cows. J. Dairy Sci. 65:2204-2212. https://doi.org/10.3168/jds.S0022 -0302(82)82483-1.

Kuhn, N. J., D. T. Carrick, and C. J. Wilde. 1980. Lactose synthesis: The possibilities of regulation. J. Dairy Sci. 63:328-336. https:// doi.org/10.3168/jds.S0022-0302(80)82934-1.

Lapierre, H., C. E. Galindo, S. Lemosquet, I. Ortigues-Marty, L. Doepel, and D. R. Ouellet. 2010. Protein supply, glucose kinetics and milk yield in dairy cows. Pages in 275-286 in Energy and Protein 
Metabolism and Nutrition. G. M. Crovetto, ed. Wageningen Academic Publishers.

Lapierre, H., G. E. Lobley, L. Doepel, G. Raggio, H. Rulquin, and S. Lemosquet. 2012. Triennial Lactation Symposium: Mammary metabolism of amino acids in dairy cows. J. Anim. Sci. 90:1708-1721. https://doi.org/10.2527/jas.2011-4645.

Lazic, S. E., C. J. Clarke-Williams, and M. R. Munafò. 2018. What exactly is ' $\mathrm{N}$ ' in cell culture and animal experiments? PLoS Biol. 16:e2005282.

Lemosquet, S., E. Delamaire, H. Lapierre, J. W. Blum, and J. L. Peyraud. 2009b. Effects of glucose, propionic acid, and nonessential amino acids on glucose metabolism and milk yield in Holstein dairy cows. J. Dairy Sci. 92:3244-3257. https://doi.org/10.3168/ jds.2008-1610.

Lemosquet, S., G. Raggio, G. E. Lobley, H. Rulquin, J. Guinard-Flament, and H. Lapierre. 2009a. Whole-body glucose metabolism and mammary energetic nutrient metabolism in lactating dairy cows receiving digestive infusions of casein and propionic acid. J. Dairy Sci. 92:6068-6082. https://doi.org/10.3168/jds.2009-2018.

Li, T., Z. Zhang, S. C. Kolwicz Jr., L. Abell, N. D. Roe, M. Kim, B. Zhou, Y. Cao, J. Ritterhoff, H. Gu, D. Raftery, H. Sun, and R. Tian. 2017. Defective branched-chain amino acid catabolism disrupts glucose metabolism and sensitizes the heart to ischemiareperfusion injury. Cell Metab. 25:374-385. https://doi.org/10 $.1016 /$ j.cmet.2016.11.005.

Lin, Y., X. Sun, X. Hou, B. Qu, X. Gao, and Q. Li. 2016. Effects of glucose on lactose synthesis in mammary epithelial cells from dairy cow. BMC Vet. Res. 12:81. https://doi.org/10.1186/s12917 -016-0704-x.

Lu, L. M., Q. L. Li, J. G. Huang, and X. J. Gao. 2012. Proteomic and functional analyses reveal MAPK1 regulates milk protein synthesis. Molecules 18:263-275. https://doi.org/10.3390/ molecules18010263.

Nishitani, S., K. Takehana, S. Fujitani, and I. Sonaka. 2005. Branchedchain amino acids improve glucose metabolism in rats with liver cirrhosis. Am. J. Physiol. Gastrointest. Liver Physiol. 288:G1292G1300. https://doi.org/10.1152/ajpgi.00510.2003.

Pabst, M., J. Grass, R. Fischl, R. Léonard, C. Jin, G. Hinterkörner, N. Borth, and F. Altmann. 2010. Nucleotide and nucleotide sugar analysis by liquid chromatography-electrospray ionization-mass spectrometry on surface-conditioned porous graphitic carbon. Anal. Chem. 82:9782-9788. https://doi.org/10.1021/ac101975k.

Räbinä, J., M. Mäki, E. M. Savilahti, N. Järvinen, L. Penttilä, and R. Renkonen. 2001. Analysis of nucleotide sugars from cell lysates by ion-pair solid-phase extraction and reversed-phase high-performance liquid chromatography. Glycoconj. J. 18:799-805. https:// doi.org/10.1023/A:1021107602535.

Riskin, A., V. H. Nannegari, and Y. Mond. 2008. Acute effectors of GLUT1 glucose transporter subcellular targeting in CIT3 mouse mammary epithelial cells. Pediatr. Res. 63:56-61. https://doi.org/ 10.1203/PDR.0b013e31815b440b.

Robinson, P. H., W. Chalupa, C. J. Sniffen, W. E. Julien, H. Sato, T. Fujieda, K. Watanabe, and H. Suzuki. 1999. Influence of postruminal supplementation of methionine and lysine, isoleucine, or all three amino acids on intake and chewing behavior, ruminal fermentation, and milk and milk component production. J. Anim. Sci. 77:2781-2792. https://doi.org/10.2527/1999.77102781x.

Ruiz-Cortes, Z. T., P. S. Yoder, and M. D. Hanigan. 2017. Essential amino acid deficiency in primary mammary epithelial bovine cells and effects on GCN2/IF2 expression and casein protein synthesis. Pages 234-235 in Society for the Study of Reproduction 50th Annual Meeting Scientific Program. Society for the Study of Reproduction (Abstr.).

Rulquin, H., and P. M. Pisulewski. 2006. Effects of graded levels of duodenal infusions of leucine on mammary uptake and output in lactating dairy cows. J. Dairy Res. 73:328-339. https://doi.org/10 $.1017 /$ S0022029906001841.
Tian, W., T. Wu, R. Zhao, J. Xu, Y. He, and H. Wang. 2017. Responses of milk production of dairy cows to jugular infusions of a mixture of essential amino acids with or without exclusion leucine or arginine. Anim. Nutr. 3:271-275. https://doi.org/10.1016/ j.aninu.2017.05.003.

Trottier, N. L., C. F. Shipley, and R. A. Easter. 1997. Plasma amino acid uptake by the mammary gland of the lactating sow. J. Anim. Sci. 75:1266-1278. https://doi.org/10.2527/1997.7551266x.

Twarog, J. M., and B. L. Larson. 1964. Induced enzymatic changes in lactose synthesis and associated pathways of bovine mammary cell cultures. Exp. Cell Res. 34:88-99. https://doi.org/10.1016/0014 $-4827(64) 90185-5$.

Wohlt, J. E., J. H. Clark, R. G. Derrig, and C. L. Davis. 1977. Valine, leucine, and isoleucine metabolism by lactating bovine mammary tissue. J. Dairy Sci. 60:1875-1882. https://doi.org/10.3168/jds .S0022-0302(77)84118-0.

Wu, H., R. Xue, Z. Tang, C. Deng, T. Liu, H. Zeng, Y. Sun, and X. Shen. 2010. Metabolomic investigation of gastric cancer tissue using gas chromatography/mass spectrometry. Anal. Bioanal. Chem. 396:1385-1395. https://doi.org/10.1007/s00216-009-3317-4.

Wu, N., B. Zheng, A. Shaywitz, Y. Dagon, C. Tower, G. Bellinger, C. H. Shen, J. Wen, J. Asara, T. E. McGraw, B. B. Kahn, and L. C. Cantley. 2013. AMPK-dependent degradation of TXNIP upon energy stress leads to enhanced glucose uptake via GLUT1. Mol. Cell 49:1167-1175. https://doi.org/10.1016/j.molcel.2013.01.035.

Xiao, C. T., and J. P. Cant. 2005. Relationship between glucose transport and metabolism in isolated bovine mammary epithelial cells. J. Dairy Sci. 88:2794-2805. https://doi.org/10.3168/jds.S0022 $-0302(05) 72959-3$

Yoder, P. S., X. Huang, I. A. Teixeira, J. P. Cant, and M. D. Hanigan. 2020. Effects of jugular infused methionine, lysine, and histidine as a group or leucine and isoleucine as a group on production and metabolism in lactating dairy cows. J. Dairy Sci. 103:2387-2404. https://doi.org/10.3168/jds.2019-17082.

Yu, Q., L. Zhu, J. Lin, Q. Zhang, Q. Tian, W. Hu, and Q. Yang. 2013. Functional analyse of GLUT1 and GLUT12 in glucose uptake in goat mammary gland epithelial cells. PLoS One 8:e65013. https:/ /doi.org/10.1371/journal.pone.0065013.

Zhang, S., Q. Yang, M. Ren, M. S. Qiao, P. He, D. Li, and X. Zeng. 2016. Effects of isoleucine on glucose uptake through the enhancement of muscular membrane concentrations of GLUT1 and GLUT4 and intestinal membrane concentrations of $\mathrm{Na}$ /glucose co-transporter 1 (SGLT-1) and GLUT2. Br. J. Nutr. 116:593-602. https://doi.org/10.1017/S0007114516002439.

Zhang, Y., S. Zhang, W. Guan, F. Chen, L. Cheng, Y. Lv, and J. Chen. 2018. GLUT1 and lactose synthetase are critical genes for lactose synthesis in lactating sows. Nutr. Metab. (Lond.) 15:40. https://doi.org/10.1186/s12986-018-0276-9.

Zhao, F. Q. 2014. Biology of glucose transport in the mammary gland. J. Mammary Gland Biol. Neoplasia 19:3-17. https://doi.org/10 .1007/s10911-013-9310-8.

Zhao, F. Q., and A. F. Keating. 2007. Expression and regulation of glucose transporters in the bovine mammary gland. J. Dairy Sci. 90:E76-E86. https://doi.org/10.3168/jds.2006-470.

\section{ORCIDS}

J. V. V. Silva @ https://orcid.org/0000-0001-9716-1932

H. K. J. P. Wickramasinghe $\odot$ https://orcid.org/0000-0002-9493-1513

C. A. Kaya (ํ) https://orcid.org/0000-0001-8226-7603

D. C. Beitz $\odot$ https://orcid.org/0000-0002-2962-5480

J. A. D. R. N. Appuhamy () https://orcid.org/0000-0001-8767-0303 